\title{
Assessment of zinc salicylate as antifouling product for marine coatings
}

\author{
Natalia Bellotti, and Roberto Romagnoli
}

Ind. Eng. Chem. Res., Just Accepted Manuscript • DOI: 10.1021/ie5015734 • Publication Date (Web): 30 Aug 2014

Downloaded from http://pubs.acs.org on September 8, 2014

\section{Just Accepted}

"Just Accepted" manuscripts have been peer-reviewed and accepted for publication. They are posted online prior to technical editing, formatting for publication and author proofing. The American Chemical Society provides "Just Accepted" as a free service to the research community to expedite the dissemination of scientific material as soon as possible after acceptance. "Just Accepted" manuscripts appear in full in PDF format accompanied by an HTML abstract. "Just Accepted" manuscripts have been fully peer reviewed, but should not be considered the official version of record. They are accessible to all readers and citable by the Digital Object Identifier (DOI®). "Just Accepted" is an optional service offered to authors. Therefore, the "Just Accepted" Web site may not include all articles that will be published in the journal. After a manuscript is technically edited and formatted, it will be removed from the "Just Accepted" Web site and published as an ASAP article. Note that technical editing may introduce minor changes to the manuscript text and/or graphics which could affect content, and all legal disclaimers and ethical guidelines that apply to the journal pertain. ACS cannot be held responsible for errors or consequences arising from the use of information contained in these "Just Accepted" manuscripts. 


\title{
Assessment of zinc salicylate as antifouling
} product for marine coatings

\author{
Natalia Bellotti ${ }^{*}$, Roberto Romagnoli \\ CIDEPINT - Centro de Investigación y Desarrollo en Tecnología de Pinturas(CIC- \\ CONICET) Calle 52 el 121 y 122. (B1900AYB) La Plata. Argentina.
}

KEYWORDS: Zinc salicylate, antifouling coatings, biofouling, biocide, leaching rate.

\begin{abstract}
The present research deals with the assessment of a new bioactive product obtained from salicylic acid, zinc salicylate ( $\mathrm{ZnSal}$ ), to be employed in antifouling coatings.

$\mathrm{ZnSal}$ was obtained in the laboratory and the procedure to precipitate it was described. Preliminary assays were carried out in the laboratory to assess its potential use in an antifouling formulation. The bioactivity of ZnSal was assessed by means of the Artemia larvae test. In a second stage soluble matrix paints were prepared with two different binders: rosin / oleic acid and rosin / styrene-acrylate copolymer. Previous to the immersion in natural environments, the coatings leaching rate in artificial sea water was monitored. Finally, the antifouling efficiency of experimental coatings was evaluated at Mar del Plata harbor, in Argentina. The coating with ZnSal and rosin / oleic acid binder proved to have an acceptable efficiency for more than twelve months.
\end{abstract}




\section{INTRODUCTION}

The colonization of hard substrates immersed in natural waters by a wide variety of marine organisms (algae, barnacles, mussels, polychaetes, ascidians, bryozoans, etc.) is commonly referred as "biofouling". Biofouling causes increased fuel consumption in vessels, due to increased hull friction with water ${ }^{1}$; metallic corrosion ${ }^{2,3}$; pipes and filtration systems blockage ${ }^{4}$; scale formation in water cooling systems; increasing in weight of off-shore sea platforms ${ }^{5}$; etc. Therefore, considering the unfavorable consequences listed above and the economic losses that they produce, the employment of adequate methodologies to prevent biofouling are mandatory ${ }^{5,6}$.

Antifouling (AF) coatings are commonly employed to prevent fouling settlement. Frequently, they are formulated with a self-polishing copolymer and one or more antifouling agents (biocides), such as $\mathrm{Cu}_{2} \mathrm{O}$ and/or organic compounds (Irgarol 1051, Diuron, Seanine, etc.). They may contain $\mathrm{ZnO}$ to improve the coating performance $^{6}$. Soluble matrix AF coatings containing the same biocides but with rosin as the binder are also commercialized ${ }^{6,7}$. These coatings dissolve in sea water and the protection did not last more than 12-18 months, because of the constant erosion that they undergo during their service life ${ }^{8,9}$. At present, there is a great interest on replacing currently biocides used by others more compatible with the environment ${ }^{10,11,12}$. In this sense, this research was focused on the assessment of $\mathrm{ZnSal}$ as an alternative AF agent. Taking into account that zinc is less toxic than copper ${ }^{13}$, the resulting coating would be more eco-friendly than those formulated with $\mathrm{Cu}_{2} \mathrm{O}$.

Some salts of organic acids have been employed as eco-friendly antifouling agents and they may be easily synthesized in the laboratory ${ }^{14,15,16}$. Particularly, ferric benzoate proved to be effective in inhibiting barnacle and most fouling organisms 
settlement during 2 month at Mar del Plata harbor ${ }^{15}$. On this basis, it was decided to use $\mathrm{ZnSal}$ as AF agent. Salicylate is found ubiquitously in plants and has been used for medicinal purposes since ancient times because of its antibacterial activity ${ }^{17}$. Zinc compounds, as zinc oxide, have been used in antifouling paints to increase their efficiency ${ }^{6,9}$.

In the first place, the aim of this research was to synthesize $\mathrm{ZnSal}$ as potential antifouling agent. Afterards, preliminary screening was carried out in the laboratory to assess its bioactivity for possible application in the of AF coatings. The tests with Artemia nauplii have the advantage of their rapidity and low cost as well as a good predictive potential; as a consequence, they constitute a valid alternative to tests with other crustacean like barnacles (Balanus Amphitrite) $)^{12,18,19}$. Finaly, AF coatings with a soluble matrix and $\mathrm{ZnSal}$ were formulated. The leaching rate these coatings in artificial sea water (ASW) was monitored periodically. Their biocidal activity was assessed in natural sea water (NSW), at Mar del Plata harbor (38 $\left.08^{\prime} 17^{\prime \prime} \mathrm{S}-57^{\circ} 31^{\prime} 18^{\prime \prime} \mathrm{W}\right)$, and qualified according to ASTM D 3623 - 78a and ASTM D6990-05 20,21 . AF coating with rosin / oleic binder and pigmented with ZnSal proved to be efficient against fouling settlement during one year.

\section{MATERIALS AND METHODS}

\subsection{Salicylic salt abstention and characterization}

ZnSal was synthesized in the laboratory after studying the solution / precipitate equilibrium, as a function of the $\mathrm{pH}$, in the sodium salicylate / zinc nitrate system. In order to obtain the precipitation curve of the $\mathrm{ZnSal}$ a solution containing: $75 \mathrm{~mL}$ of salicylic acid $0.01 \mathrm{M}, 5 \mathrm{~mL}$ of zinc nitrate $0.05 \mathrm{M}$ and $5 \mathrm{~mL}$ of hydrochloric acid $0.05 \mathrm{M}$ was prepared, placed in a beaker and titrated with $0.05 \mathrm{M}$ sodium. The $\mathrm{pH}$ of the 
solution was measured with a glass electrode. Sodium hydroxide solution was standardized using potassium acid phthalate as primary pattern.

The synthesis of $\mathrm{ZnSal}$ was started from ammonium salicylate due to the low solubility of salicylic acid in water $\left(1.8 \mathrm{~g} / \mathrm{L}\right.$ at $\left.20^{\circ} \mathrm{C}\right)$ which would limit the amount of $\mathrm{ZnSal}$ to be obtained. Therefore, $700 \mathrm{~mL}$ of $0.9 \mathrm{M}$ ammonium salicylate was placed in a container and $800 \mathrm{~mL}$ of $0.4 \mathrm{M}$ zinc nitrate were added drop wise under continuous stirring at room temperature. The precipitation $\mathrm{pH}$ must be adjusted to 6.8 according to results from the precipitation curve of $\mathrm{ZnSal}$. The next day, $\mathrm{pH}$ was readjusted, the precipitated was centrifuged, washed with distilled water (DW), air dried at room temperature and milled.

The amount of free water in ZnSal was determined by indirect gravimetric, heating the solid at $105 \pm 5^{\circ} \mathrm{C}$. Zinc was determined as zinc oxide by a gravimetric procedure heating the solid at $900^{\circ} \mathrm{C}$. The organic fraction was calculated as the difference between the mass of dried $\mathrm{ZnSal}$ and the zinc content; from this data the stoichiometry of ZnSal was obtained. The FTIR spectrum of ZnSal was obtained using the potassium bromide disc technique and a Perkin-Elmer Spectrum One FTIR Spectrometer. The density of the pigment, needed for coating formulation, was determined according to ASTM D $153-84^{22}$.

\subsection{Bioassay}

$\mathrm{LC}_{50}$, the concentration which kills $50 \%$ of the Artemia nauplii population within 24 hours, was determined using a short term toxicity test ${ }^{19}$.

Artemia persimilis eggs, commercially available, were hatched in artificial sea water (ASW), at $22 \pm 2^{\circ} \mathrm{C}$ during 24 hours, under gentle aeration with an aquarium pump ${ }^{23}$. 
The ASW was prepared according to ASTM D1141-98 ${ }^{24}$. After 48 hours a homogenous population of instar II-III nauplii were obtained and used for the test. A saturated solution of ZnSal in ASW was prepared and the concentration of salicylate ions was measured by UV-vis spectrophotometry at $297 \mathrm{~nm}^{25}$. This concentrated solution was diluted to obtain different concentrations of the salt (typically: 1000, 500, 250, 125, 75 ppm) to perform the test with the Artemia larvae, following the same procedure outlined in previous published research ${ }^{12,18}$. After an incubation period of $24 \mathrm{~h}$, dead larvae were counted and $\mathrm{LC}_{50}$ values were calculated by Probit analysis ${ }^{26}$.

\subsection{Formulation and preparation of coatings}

Two coatings, with two different binders, were formulated to carry out this research (Table 1). Coating 1 contained WW rosin as film forming material and oleic acid as plasticizer; aluminum stearate was added as rheological agent ${ }^{27}$. Coating 2 was formulated with styrene-acrylate copolymer (SAC) as co-binder being 1.9/1 the ratio rosin/SAC by volume (Table 1). In this case, the plasticizer was chlorinated paraffin with $42 \%$ of chloride. This plasticizer is commonly recommended for the styreneacrylate copolymer and is also compatible with the rosin resin ${ }^{28}$. Coatings were elaborated following a procedure described in the literature ${ }^{12,18}$.

Control coatings were also elaborated with the same formula of coating 1 and 2, respectively, but replacing $\mathrm{ZnSal}$ in volume by $\mathrm{TiO}_{2}$.

\subsection{Determination of leaching rates in ASW}

The leaching rate test in ASW, is a short term test to assess the dissolution of active agent from coatings in laboratory conditions previous to immersion in natural sea water. Coatings were applied on $8 \times 8 \mathrm{~cm}$ sandblasted acrylic panels. Three or four 
coats were applied and allowed to dry 24 hours between each application. The total dry film thickness was $120 \pm 5 \mu \mathrm{m}$. Not more than 48 hours elapsed for the painted panels to be submerged in a plastic container containing $150 \mathrm{ml}$ of ASW. The leached salicylate was determined by UV-Vis spectrophotometry while zinc was determined by atomic absorption spectroscopy. The original level of the liquid in the containers was restored periodically with distilled water and the $\mathrm{pH}$ was adjusted to 8.2.

\subsection{Essays in NSW}

Sandblasted acrylic panels $(8 \times 12 \mathrm{~cm})$ were coated as described before to match a total dry film thickness of $180 \pm 5 \mu \mathrm{m}$. No more than 48 hours elapsed before the painted panels were immersed in Mar del Plata harbor $\left(38^{\circ} 08^{\prime} 17^{\prime \prime} \mathrm{S}-57^{\circ} 31^{\prime} 18^{\prime \prime} \mathrm{W}\right)$. The coastal area where the trial was performed is subjected, predominantly, to atmospheric thermal cycling. The seawater temperatures exhibited seasonality with an average maximum of $20^{\circ} \mathrm{C}$ during February and a minimum of $9.3^{\circ} \mathrm{C}$ during July. The salinity ranged between 32.6 and 34.6 o/oo.

The biofouling resistance was evaluated according to ASTM D $3623-78 \mathrm{a}$ and ASTM D $6990-05^{30,31}$. The range for the fouling rating (FR) was 0 to 100 . The FR for coatings free of adherent biofouling settlement was recorded as 100 . The FR of each coating was obtained by discounting from 100 the percentage of the area covered by macrofouling. A coating free of macrofouling settlement, but with adherent slime (microorganisms such as bacteria, fungi, diatoms and protozoa), was qualified with a $\mathrm{FR}=99$, whichever the percentage of the covered area was. Therefore, fouling rating reflects non-fouled area. Distance smaller than $1 \mathrm{~cm}$ from the edge of the panels were not considered. Uncoated panels were used as control and immersed in the same conditions as the painted ones. Barnacles, serpulids, ascidians, bryozoans, algae and 
polychaetes are frequent macrofouling organisms at Mar del Plata harbor and may be found attached onto the panels ${ }^{4,29}$. This assay was conducted in triplicate.

Microscopic examination of coating 1 (the more efficient coating exposed to NSW) during a short time (2 days) was carried out by environmental scanning electron microscopy (ESEM) employing a PHLLIPS FEI Quanta 200, in order to assess microfouling settlement. The biological structures were preserved with a $2.5 \%$ glutaraldehyde solution and stored in sea water until their observation ${ }^{2,30}$.

\section{RESULTS AND DISCUSSION}

\subsection{Salicylic salt abstention and characterization}

The precipitated $\mathrm{ZnSal}$ was in equilibrium with its own ions at $\mathrm{pH} 6.8$ (Figure 1). The determination of the $\mathrm{pH}$ value is of importance with respect to the synthesis procedure to obtain the salicylate derivative with a definite composition. The chemical composition of $\mathrm{ZnSal}$ was as follows: salicylate, $63.30 \%$; zinc $24.20 \%$, being the rest $(12.50 \%)$ water. According to these results the molar ratio between the salicylate anion and the zinc cation was calculated and found to be $\sim 1: 1$.

The main absorption bands detected in the FTIR spectrum were in accordance with the chemical composition of the $\mathrm{ZnSal}$. The intense band at $3600 \mathrm{~cm}^{-1}$ corresponds to the stretching of the $\mathrm{OH}$ groups (Figure 2). The asymmetric and symmetric $-\mathrm{COO}^{-}$ stretching produce two strong bands usually present in a sample with carboxilate groups, therefore the peaks at 1600 and $1403 \mathrm{~cm}^{-1}$ could be assigned to these ions ${ }^{30}$. The peaks at 1540 and $1456 \mathrm{~cm}^{-1}$ correspond to the stretching of the $\mathrm{C}=\mathrm{C}$ bond of the aromatic ring. The sharp peak at $1235 \mathrm{~cm}^{-1}$ corresponds to the stretching of the C-O bonded to the aromatic ring and the peak next to $1093 \mathrm{~cm}^{-1}$ corresponds to the vibration 
of the $\mathrm{C}-\mathrm{O}$ bond $^{32,33}$. These observations led to the conclusion that zinc ions would be interacting with the carboxilate groups.

The density of ZnSal was $1.80 \mathrm{~g} / \mathrm{cm}^{3}$. The solubility of $\mathrm{ZnSal}$ in AMA was determined by UV spectrophotometry at $297 \mathrm{~nm}$, a wavelength at which ZnSal presents an absorption maximum. It was found to be equal to $10143 \mathrm{ppm}$. The concentration of $\mathrm{Zn}^{2+}$, in the same solution, determined by atomic absorption, was $1052 \mathrm{ppm}$.

\subsection{Bioassays}

After an incubation period of $24 \mathrm{~h}$, the $\mathrm{ZnSal} \mathrm{LC}_{50}$ was found to be $627 \pm 56$ $\mathrm{mg} / \mathrm{l}$ (salicylate) and $7 \pm 2.0 \mathrm{mg} / \mathrm{l}$ for copper sulphate (positive control). These results showed that SalZn has some activity against Artemia persimili larvae; however, its toxicity is much lower than that of copper sulfate because the dose to achieve $\mathrm{LC}_{50}$ is significantly higher for ZnSal.

\subsection{Determination of leaching rates in ASW}

Results of leaching experiments are shown in Figure 3 to 5. The reproducibility of the test was acceptable and the variation coefficient between measurements was $4 \%$. As a general rule, it can be seen that coating 1 , formulated with rosin and oleic acid, leached a higher amount of salicylate as it could be observed in the cumulative leached mass plot (Figure 3). Coating 1 was observed, principally, during the first fortnight of immersion (Figure 3 and 4). It is also remarkable that coating 2 leached more salicylate than coating 1 during the first 3 days of the trial. At the end of the trial, both coatings showed a leaching rate close to $1.0 \mu \mathrm{g} . \mathrm{cm}^{-2}$.day ${ }^{-1}$ of salicylate. During the first days of testing, there was a sharp drop in the leaching rate of coatings 1 and 2 (Figure 3). This descent could be attributed to the fact that, at the beginning of the 
immersion period, the bioactive agent was close to the film surface and, as a consequence, it could be leached easily. As time elapsed the biocide must diffuse from the inner of the coating to the surface. It is clear that coating 1 offered better diffusion path for ZnSal which, in turn, was reflected in the higher values of the leached salicylate. After 10 days both coatings presented a similar behavior.

At the beginning of the assay, the leaching rate of $\mathrm{Zn}^{2+}$ from coatings 2 was higher than from coating 1 (Figure 5) but, at the end of the test, both values approached to $0.3-0.4 \mu \mathrm{g} . \mathrm{cm}^{-2}$.day ${ }^{-1}$. As sea water $\mathrm{pH}$ is $\sim 8.2$, close to the precipitation of zinc hydroxide, it was expected that zinc ions tend to precipitate which will increase the release of salicylate ions to the medium. This may explain the larger amount of salicylate ions leached in relation to zinc ions during the first period of immersion before the 20 days.

These results were important because they showed that lower amounts of metals would be released to the environment during the coatings service life. According to bibliographic data, $\mathrm{Zn}^{2+}$ ions leaching rate from biocide-free commercial AF paints is approximately 20 to 27 times higher than the value determined in this research ${ }^{9,34}$.

\subsection{Essays in NSW}

The panels submerged in natural sea water were observed periodically and the assay was conducted in triplicate. After six months, coatings 1 and 2 performed notoriously better than the controls (Figure 6.a-b). FR of the control panels was found to be 15 and it continued decreasing with time. The predominant macrofoulers were ascidians, bryozoans, serpulids and algae. These results confirmed the antifouling activity of $\mathrm{ZnSal}$ which was assessed previously by laboratory test. 
The control coating 1 had a low FR $(\sim 10)$ after one year of exposition but panels with coating 1 exhibited a FR=95 at the same period of time, Figure 6 a. Panels with the control coating were completely covered with ascidians, algae, serpulids, barnacles and bryozoans at the end of the trial and, at the same time, they showed an incipient film wearing since 6 months on. Coating 1 was more resistant than control coating. After 15 months of exposition coating 1 showed a high wear and, therefore, panels were removed from the test site, Figure 6 a. The fouling attached onto the panels consisted mostly of a heavy slime and algae. It is encouraging that $\mathrm{ZnSal}$ effectiveness in fouling control was maintained even in the case of worn film.

Coating 2 resulted to be less efficient than coating 1 with a FR=60 after six months which descended to 30 when nine months of immersion elapsed, Figure $6 \mathrm{~b}$. At the beginning of the immersion period a thick slime layer was deposited quickly onto the panels. After six months the most frequent organisms found attached onto the panels were bryozoans and serpulids. However, film integrity was kept until the ninth month. The panels corresponding to the control coating 2 were almost totally fouled $(\mathrm{FR}=5)$ after six months; mostly with ascidians and serpulids, Figure 6 b. Due to the lower efficiency of the coating 2 , the panels were removed at the ninth month. These results showed that the antifouling activity was highly influenced by the nature of the binder. The incorporation of SAC improved film resistance but affected the coating leaching rate causing the antifouling performance to decrease.

Controls for coating 1 and 2 did not contain ZnSal, but less fouling was observed in the first, especially in 6 and 9 months. This should be due to a higher erosion rate associated with a higher content of rosin. 
The ESEM micrographs of the control coating 1 and those of the coating 1 before and after the exposure to NSW, are shown at the Figure 7. Previous to the immersion both coatings showed a homogeneous and compact film, especially coating 1. After 2 days of immersion in NSW a great degree of colonization was observed on the control coating 1 which exhibited an abundant biofilm with emergence of diatoms and protozoa. Coating 1 did not present biofilm formation but pores appeared as a consequence of binder solubilization. These pores could not be seen on the control coating due to the thick biofilm formed. This result confirmed the fact that $\mathrm{ZnSal}$ inhibited the growth of microfouling.

\section{CONCLUSIONS}

ZnSal showed to be active against Artemia larvae and it has a lower toxicity than copper. Coating 1 had longer service life than coatings 2 with a fouling rating above 95 until the twelfth month of immersion.

The coating with $\mathrm{ZnSal}$ and rosin / oleic acid binder proved to have an acceptable efficiency for more than twelve months. According to data published, ferric benzoate, ferric and aluminum sorbate were assessed in field test ${ }^{15,16}$ to determine their antifouling efficiency in coatings with a similar binder, but their service life was, approximates, 9 months. In change, similar coatings pigmented with $\mathrm{ZnSal}$ proved to have an extended service life. The use of styrene-acrylate copolymer on coating 2, increased the film resistance to wearing, with respect to coating 1 , but the antifouling performance was impaired, due to a decreased leaching rate. Results obtained with coating in NSW showed that ZnSal can be used as an effective antifoulant. 


\section{FIGURES CAPTIONS}

Figure 1. Titration curve of salicylic acid + zinc nitrate with $0.05 \mathrm{M} \mathrm{NaOH}$

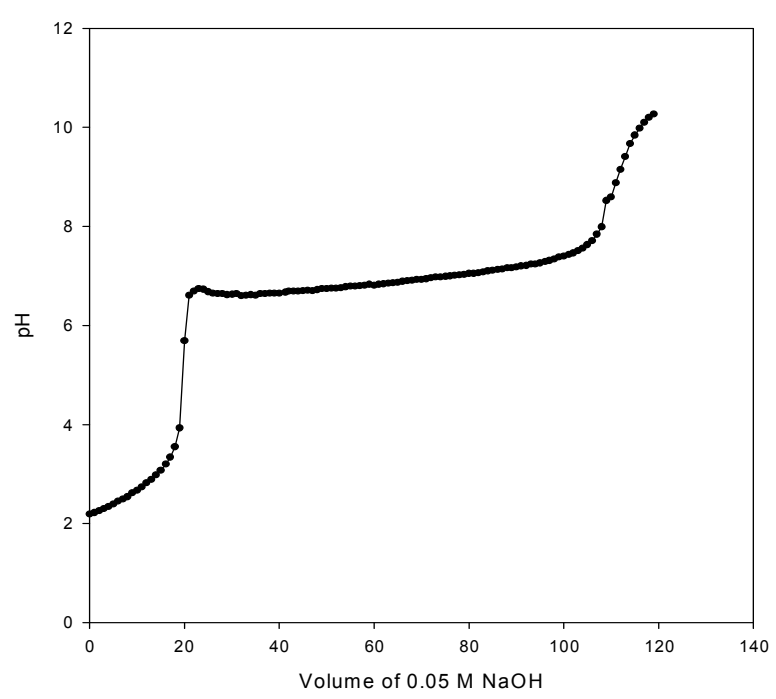

Figure 2. FTIR spectrum of zinc salicylate.

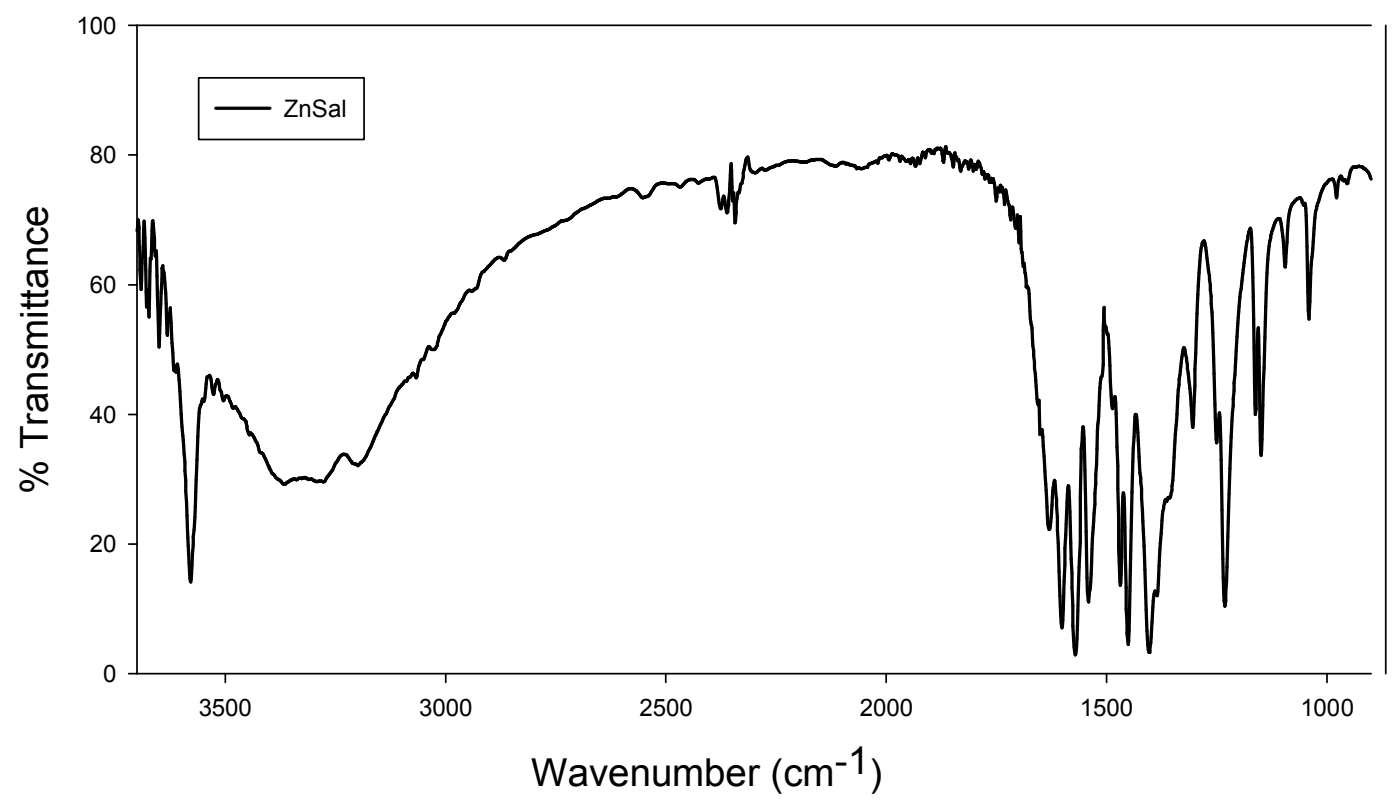


Figure 3. Amount of salicylate leached from coating films.

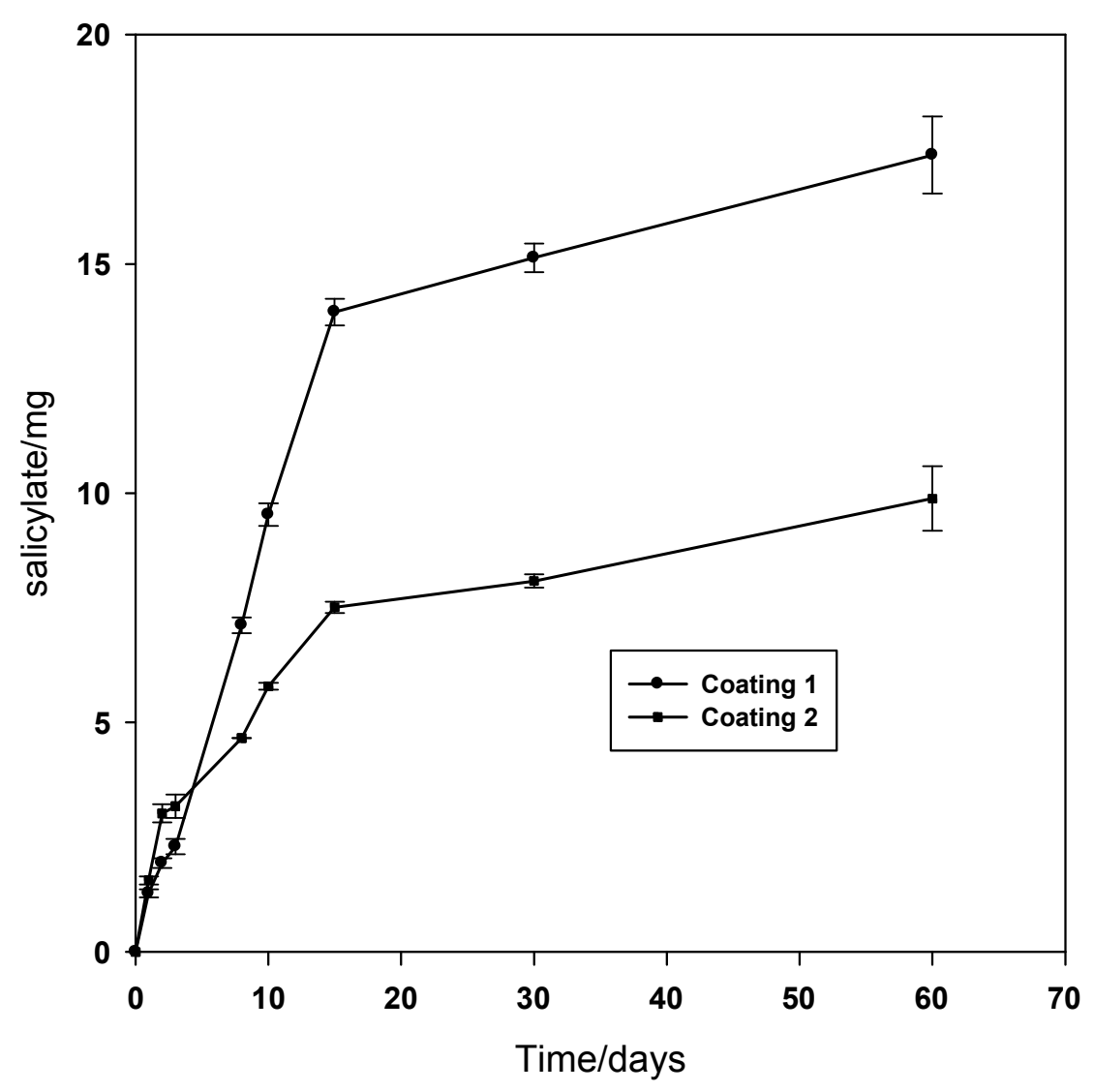

1

2

3

4

5

6

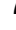

10

11

12

13

14

15

16

17

18

19

20

21

22

23

24

25

26

27

28

29

30

31

32

33

34

35

36

37

38

39

40

41

42

43

44

45

46

47

48

49

50

51

52

53

54

55

56

57

58

59

60 
Figure 4. Salicylate leaching rate from coating films.

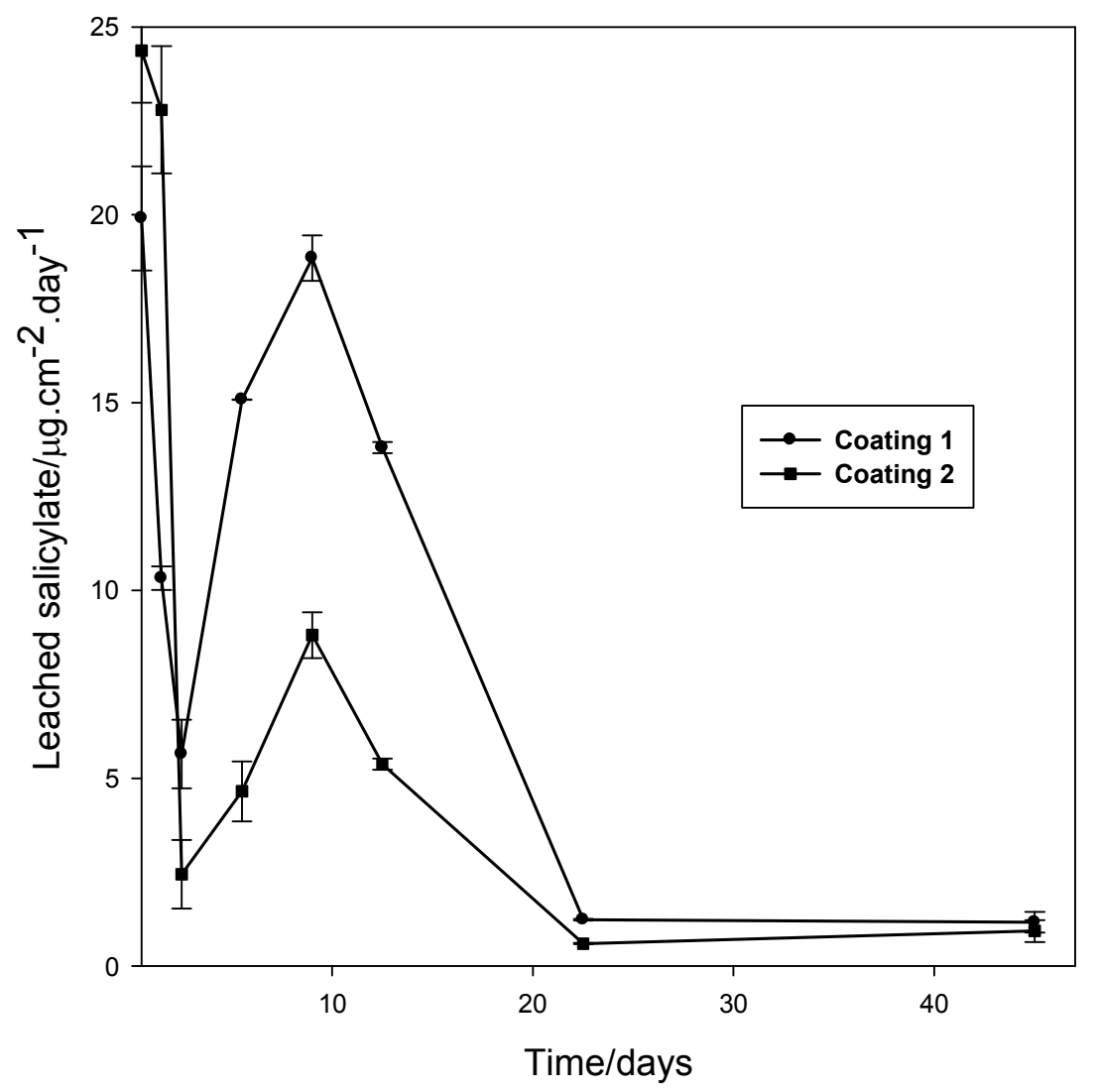


Figure 5. Zinc ions leaching rate from the coating films.

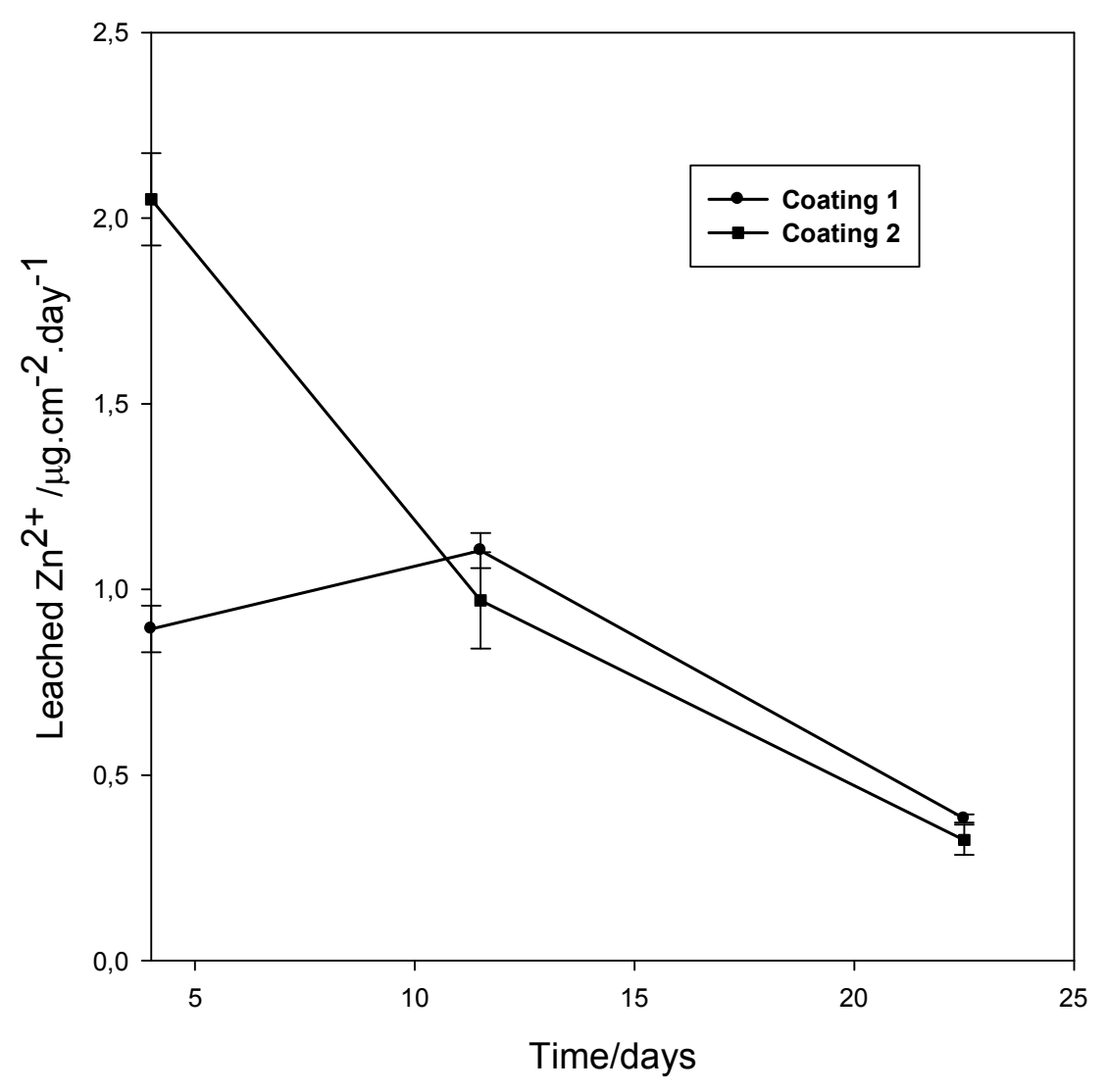

1

2

3

4

5

6

7

10

11

12

13

14

15

16

17

18

19

20

21

22

23

24

25

26

27

28

29

30

31

32

33

34

35

36

37

38

39

40

41

42

43

44

45

46

47

48

49

50

51

52

53

54

55

56

57

58

59

60 
Figure 6 a. Photographs of panels (coating 1 and controls) immersed in sea water at Mar del Plata harbor, Argentina $($ bar $=1 \mathrm{~cm})$.
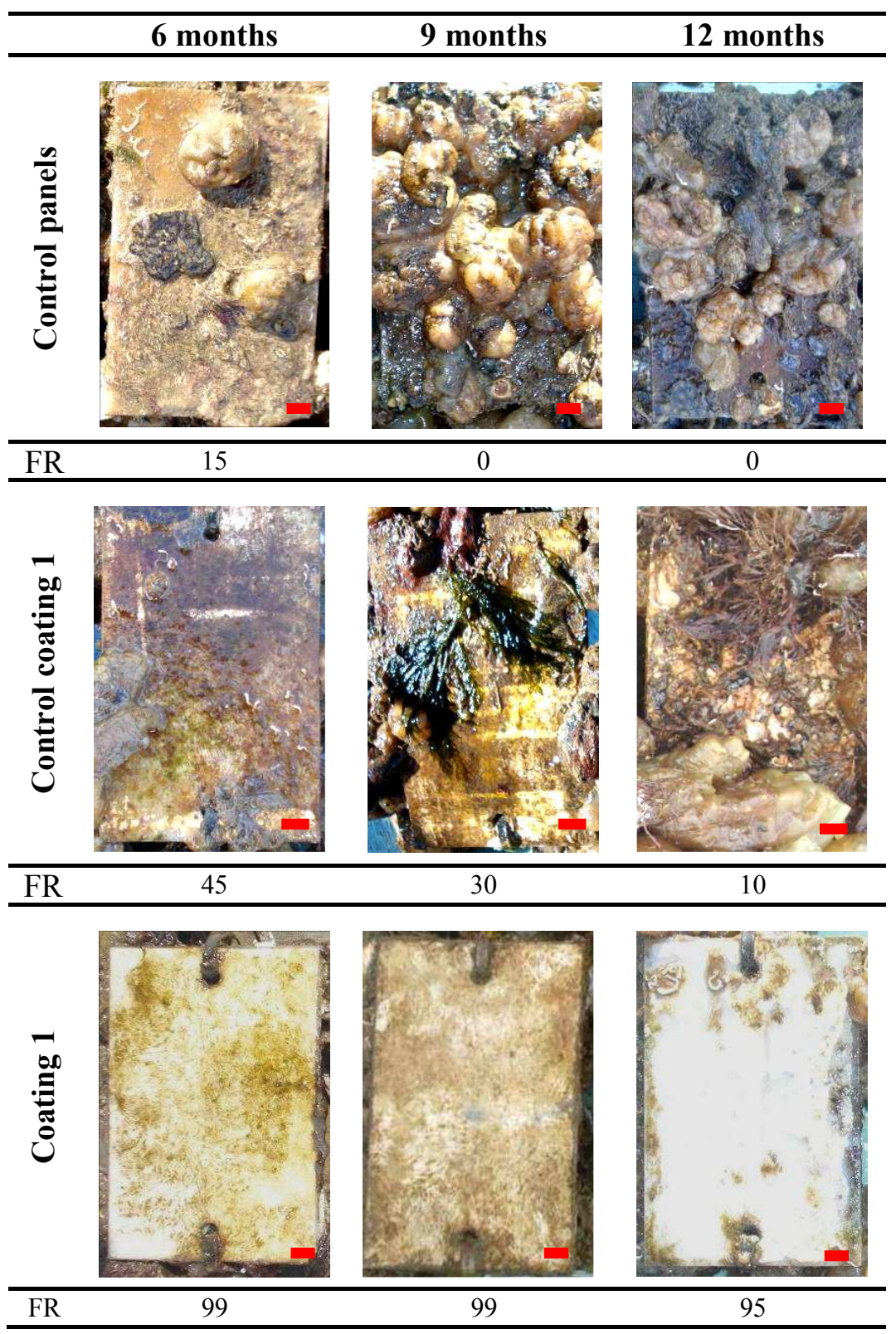
Figure 6 b. Photographs of panels (coating 2 and controls) immersed in sea water at Mar del Plata harbor, Argentina (bar $=1 \mathrm{~cm})$.

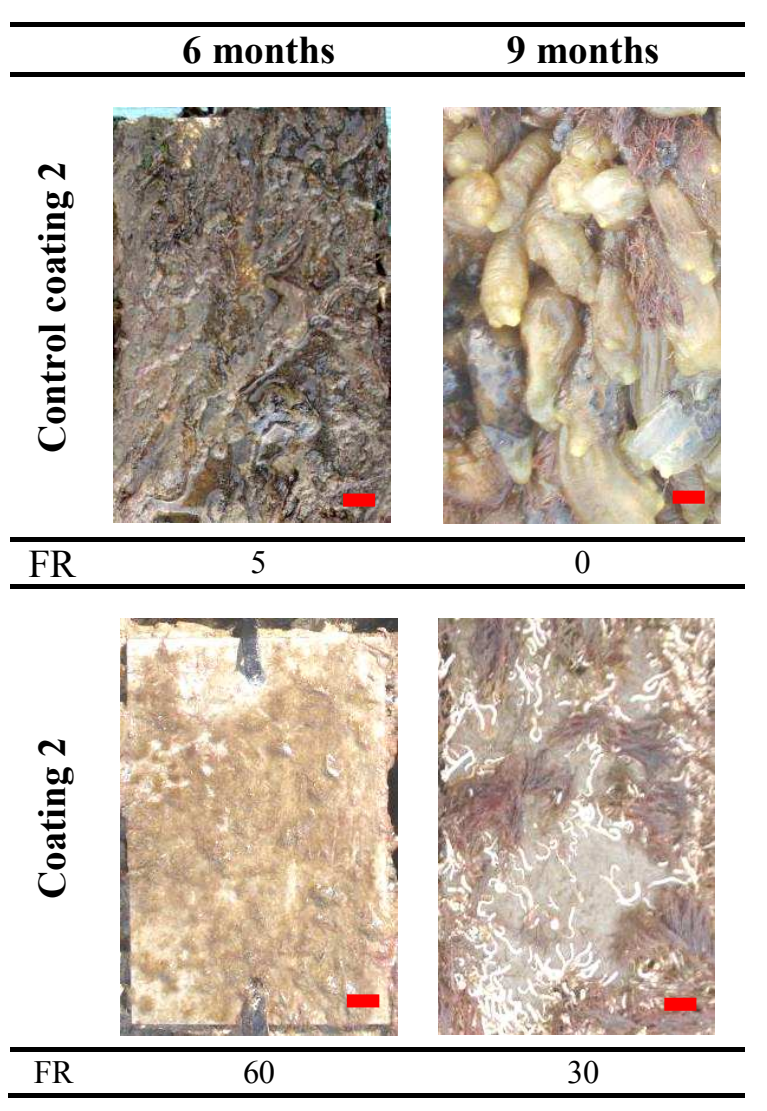


Figure 7. ESEM micrograph: panels without and with 2 days of immersion in NSW, water at Mar del Plata harbor, Argentina.
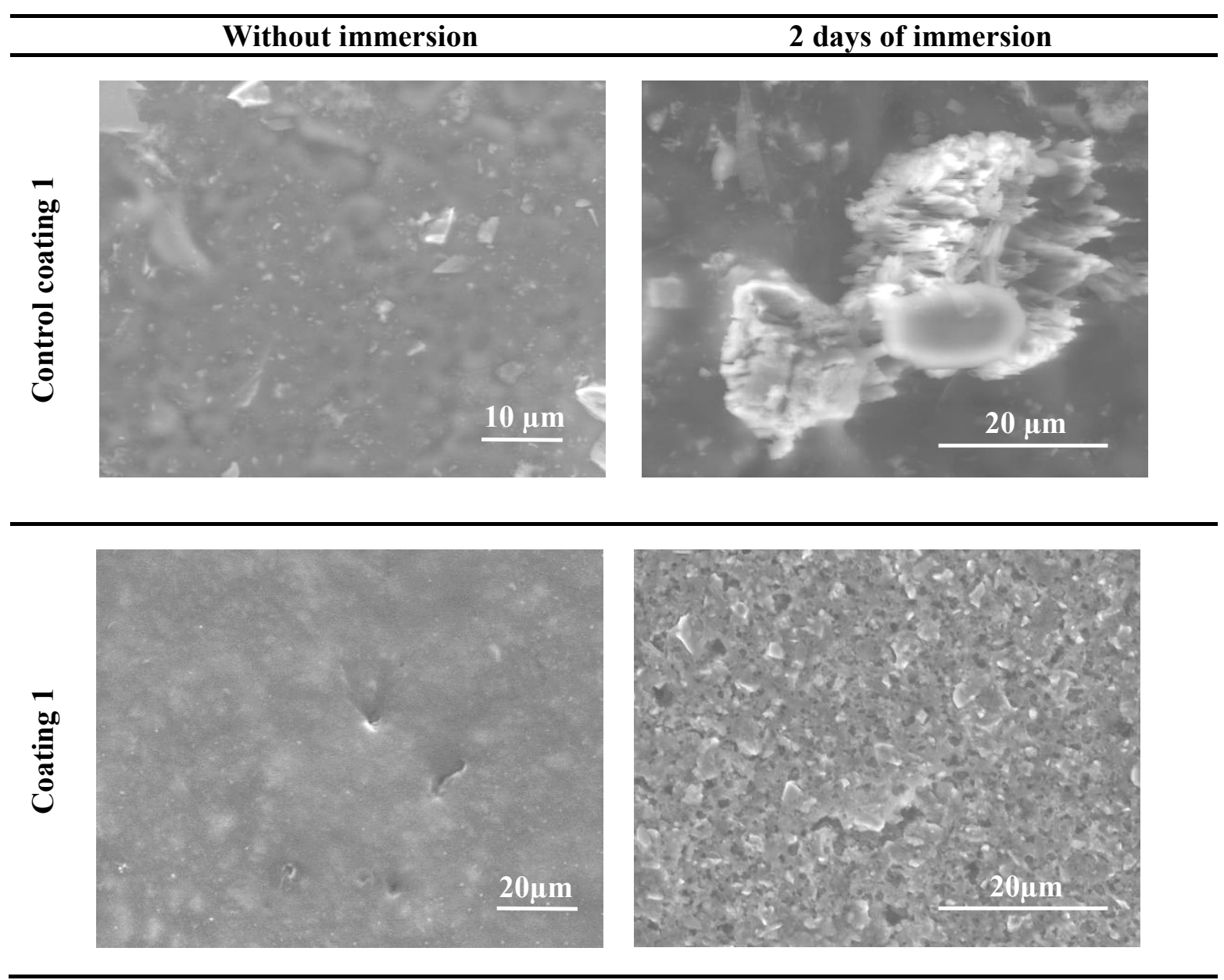


\section{TABLES}

Table1. Composition of paints as $\%$ of solids by volume

\begin{tabular}{|c|c|c|}
\hline Components & Coating $1^{\mathrm{a}}$ & Coating 2 \\
\hline SalZn & 27.0 & 34.6 \\
\hline Chalk & 18.1 & 8.8 \\
\hline WW rosin & 45.1 & 32.8 \\
\hline SAC & ------ & 17.2 \\
\hline Chlorinated paraffin & ----- & 6.6 \\
\hline Oleic acid & 9.8 & ------ \\
\hline
\end{tabular}

${ }^{\text {a }}$ Coating 1 was prepared with a $2.0 \mathrm{wt} . \%$ content aluminium stearate. 


\title{
AUTHOR INFORMATION
}

\section{Corresponding Author}

*E-mail: pinturashigenicas@cidepint.gov.ar

\author{
Notes \\ Both authors are CONICET Researchers and UNLP Professors.

\section{ACKNOWLEDGMENTS}

The authors wish to thank the Consejo Nacional de Investigaciones Científicas y Técnicas (CONICET), Comisión de Investigaciones Científicas de la Provincia de Buenos Aires (CIC), Agencia Nacional de Promoción Científica y Tecnológica (ANPCyT) and the Universidad Nacional de La Plata (UNLP) for the support to do this research. They also thank to Gastón Guzmán for the analytical determinations.

\section{REFERENCES}

(1) Schultz, M.P. Effects of coating roughness and biofouling on ship resistance and powering. Biofouling. 2007, 23, 331.

(2) Baier, R.E. Adsortion of microorganisms to surfaces; Wiley-Interscience Publication: USA, 1980.

(3) Beech, I.B.; Sunner, J. Biocorrosion: towards understanding interactions between biofilms and metals. Curr Opin Biotechnol. 2004, 15, 181.

(4) Bastida, R.; Martin, J.P. La vida entre mareas: vegetales y animales de las costas de Mar del Plata. Mar del Plata; INIDEP: Mar del Plata, 2004. 
(5) Apolinario, M.; Couthino, R. Advances in marine AF coatings and technologies; Woodhead Publishimg: UK, 2009.

(6) Yebra, D.M.; Kiil, S.; Dam-Johansen, K. Antifouling technology—past, present and future steps towards efficient and environmentally friendly antifouling coatings. Prog. Org. Coat. 2004, 50, 75.

(7) Almeida, E.; Diamantino, T.C.; de Sousa, O. Marine paints: the particular case of antifouling paints. Prog. Org. Coat. 2007, 59, 2.

(8) Chambers, L.D.; Stokes, K.R.; Walsh, F.C.; Wood, R.J.K. Modern approaches to marine antifouling coatings. Surf. Coat. Tech. 2006, 201, 3642.

(9) Ytreberg, E.; Karlsson, J.; Eklund, B. Comparison of toxicity and release rates of Cu and $\mathrm{Zn}$ from anti-fouling paints leached in natural and artificial brackish seawater. Sien. Total Environ. 2010, 408, 2459.

(10) Konstantinou, I.K. Antifouling Paint Biocides; Springer: New York, 2006.

(11) Bellotti, N.; Deyá, C.; del Amo, B.; Romagnoli, R. Antifouling Paints with Zinc “Tannate”. Ind. Eng. Chem. Res. 2010, 49, 3386.

(12) Bellotti, N.; del Amo, B.; Romagnoli, R. Quaternary Ammonium “Tannate" for Antifouling Coatings, Ind. Eng. Chem. Res. 2012, 51, 16626.

(13) Nriagu, J.O. Cinc in the environmenta, Part 1: Ecological Cycling; Wiley: USA, 1980. 
(14) Blustein, G.; Romagnoli, R.; Jaén, J.A.; Di Sarli, A.R.; del Amo, B. Zinc basic benzoate as eco-friendly steel corrosion inhibitor pigment for anticorrosive epoxycoatings. Coll. Surf. A: Phys. Eng. Aspects. 2006, $290,7$.

(15) del Amo, B.; Blustein, G.; Pérez, M.; García, M.; Deyá, M.; Stupak, M.; Romagnoli, R. A multipurpose compound for protective coatings. Coll. Surf. A: Phys. Eng. Aspects. 2008, 324, 58.

(16) Pérez M.; García M.; Stupak M. and Blustein G. Synthesis and Characterization of Ferric Sorbate and Aluminum Sorbate as Antifouling Pigments for Marine Paints. Ind. Eng. Chem. Res. 2014, 53, 3570.

(17) Price, C.T.D.; Lee, I. R.; Gustafson, J. E. The effects of salicylate on bacteria. Int. J. Biochen. Cell Biol. 2000, 32, 1029.

(18) Bellotti, N.; del Amo, B.; Romagnoli, R. Tara tannin a natural product with antifouling coating application. Prog. Org. Coat. 2012, 74, 411.

(19) Persoone, G.; Wells, P.G. Artemia Research and its Applications. Vol.1. Morphology, Genetics, Strain characterization, Toxicology; University Press: Belgium, 1987.

(20) ASTM D 3623 - 78a. Standard test method for testing antifouling panels in shallow submergence; ASTM international: USA, 2004.

(21) ASTM D 6990-05. Standard practice for evaluating biofouling resistance and physical performance of marine coating systems; ASTM International: West Conshohocken, PA, USA, 2005. 
(22) ASTM D 153-84. Standard test methods for specific gravity pigments; ASTM International: West Conshohocken, PA, USA, 2003.

(23) Persoone, G.; Jaspers, E.; Clasus, C. Ecotoxicological Testing for the Marine Environment: Proceedings of the International Symposium on Ecotoxicological Testing for the Marine Environment, Ghent, Belgium; State University of Ghent: Ghent, Belgium, 1984.

(24) ASTM D 1141-98. Standard practice for the preparation of substitute ocean water; ASTM International: West Conshohocken, PA, USA, 2008.

(25) Snell, F.D.; Snell, C.T. Colorimetric Methods of Analysis. D. Van Nostrand Company: New York, 1941.

(26) Díaz Baez, M. C.; Bulus Rossini, G. D.; Pica Granados, Y. Métodos estadísticos para el análisis de resultados de toxicidad. In Ensayos Toxicológicos y Métodos de Evaluación de Calidad de Aguas: Estandarización, intercalibración, resultados y aplicaciones; Castillo Morales, G., Ed.; IDRC Books: Ottawa, Canada, 2004.

(27) Pérez, M.; Blustein, G.; García, M.; del Amo, B.; Stupak, M. Cupric tannate: A low copper content antifouling pigment. Prog. Org. Coat. 2006, 55, 311.

(28) Stoye, D.; Freitag, W. Paints, Coatings and Solvents. WILEY-VCH: Fed. Rep. of Germany, 1998.

(29) Bastida, R.; Capezzani, A.; Torti, M.R. Fouling organisms in the port of Mar del Plata (Argentina). I.Siphonaria lessoni: ecological and biometric aspects. Mar. Biol, 1971, 10, 297. 
(30) Callow, J.A.; Osborne, M.P.; Callow, M.E.; Baker, F.; Donald, A.M.; Use of environmental scanning electron microscopy to image the spore adhesive of the marine alga Enteromorpha in its natural hydrated state. Coll. Surf. B: Bioint. 2003, 27, 315.

(31) Smith, B. Infrared Spectral Interpretation, 1st ed.; CRC Press: New York, 1999.

(32) Cooper, J.W. Spectropic techniques for Organic Chemists, 1st ed.; WileyIntercience Publication: New York, 1980.

(33) Morrison, R.T.; Boyd, R.N. Química Orgánica, Addison-Wesley Iberoamericana: Wilmington, DE, 1990.

(34) Yebra, D.M., Kiil , S., Dam-Johansen, K. Weinell, C.E., Reaction rate estimation of controlled-release antifouling paint binders: Rosin-based systems. Prog. Org. Coat. $\mathbf{2 0 0 5}, 53,256$. 